\title{
Assessment of Health-Related Quality of Life and Associated Factors Among HIVIAIDS Patients on Highly Active Antiretroviral Therapy (HAART) at Ambo General Hospital, West Shewa, Ethiopia
}

This article was published in the following Dove Press journal:

HIVIAIDS - Research and Palliative Care

Hunduma Dinsa Ayeno $\mathbb{D}$

Kume Megersa Atomsa

Getu Melesie Taye

Department of Pharmacy, College of Medicine and Health Sciences, Ambo University, Ambo, Ethiopia
Correspondence: Hunduma Dinsa Ayeno Email dhunduma@gmail.com
Background: Determining the degree of health-related quality of life (HRQoL) and associated factors in human immunodeficiency virus (HIV)-positive people is of great importance.

Objective: The aim of this study was to assess the HRQoL and associated factors among HIV-infected patients who were on highly active antiretroviral therapy (HAART) at Ambo General Hospital.

Methods: A study with a cross-sectional design was conducted on 296 HIV-infected patients who were on HAART at Ambo General Hospital from February 20 to May 20, 2019. Patients were recruited by a random sampling technique and a $P$-value $<0.05$ was set as statistically significant. Th main outcome measure was HRQoL.

Results: The majority of study participants were female $(56.8 \%)$. More than half $(53 \%)$ of the participants had low overall HRQoL. Those who were married and who earned $<1500$ ETB were less likely to experience low overall HRQoL than single people (AOR: 4.41, $P=0.024$ ) and those who earned more (AOR: 4.27, $P=0.000$ ), respectively. Those with current illness and who had no HIV-positive family members were more likely to experience lower overall quality of life than those with no current illness (AOR: 32.29, $P=0.000$ ) and with one HIV-positive family member (AOR: 4.03, $P=0.003$ ), respectively. Those with recent WHO clinical stage I were less likely to experience a lower overall quality of life than those with stage II (AOR: 0.07, $P=0.000$ ).

Conclusion: Current illness, recent WHO stage and having no HIV-positive family members were found to be strongly associated with lower quality of life in HIV-positive patients on antiretroviral therapy.

Keywords: health-related quality of life, HIV-positive patients, highly active antiretroviral therapy, Ambo General Hospital, WHO stage IV

\section{Background}

Human immunodeficiency virus (HIV) affects immune cells, abolishing or weakening their function. Acquired immune deficiency syndrome (AIDS) is the most advanced stage of HIV infection. It is characterized by the manifestation of any of more than 20 opportunistic infections (OIs) or HIV-related cancers. ${ }^{1}$ The Joint United Nations Programme on HIV/AIDS (UNAIDS) reveals that around 36.9 million people globally are living with HIV/AIDS and approximately 
1.8 million people were newly infected with HIV/AIDS at the end of $2017 .^{2}$ Almost $95 \%$ of HIV-infected people are living in developing countries. Approximately $70 \%$ of HIV-infected patients are living in Sub-Saharan Africa. ${ }^{3}$ The HIV prevalence among the adult population in Ethiopia was projected to be $1.16 \%$ in $2016 .{ }^{4}$

The treatment regimen recommended to aggressively suppress viral replication and halt the progression of HIV infection is highly active antiretroviral therapy (HAART). More than 10 years of experience in the use of HAART in all World Health Organization (WHO) European Region countries have led to better survival, reduced mortality and great improvement in quality of life (QoL). ${ }^{5}$ However, questions have been raised about how the use of HAART changes the health-related quality of life (HRQoL) of people living with HIV/AIDS (PLWHA) in developing countries. $^{6}$

The WHO has defined QoL as individuals' perceptions of their position in life in the context of the culture and value systems in which they live, and in relation to their goals, standards, expectations and concerns. ${ }^{7}$ This explanation highlights the significance of a global personal feeling of well-being relating to aspects of optimism, pleasure and satisfaction. QoL, therefore, describes both satisfaction of material circumstances and how pleased an individual is with these circumstances of life. ${ }^{8}$

A radical change in QoL and the consequent capability of the patient to continue with a normal life, including assisting their family and being productive, will inspire long-term treatment provision. However, if HRQoL is poor, it will have a harmful effect on the lifelong adherence to medications. ${ }^{9}$ A study of HRQoL presented an assessment of the influence of treatment in chronic illnesses, for which improvement in functional status and well-being can be considered as a crucial outcome. ${ }^{10}$

By looking into the sense of well-being and pleasure experienced by people under their current life circumstances, the assessment of HRQoL aims to provide a complete evaluation of the individual's well-being, which includes an assessment of their role functioning, community integration and personal adjustment. ${ }^{11} \mathrm{HIV}$ infection mostly affects physical, psychological, level of independence, social, environmental and spiritual domains of HRQoL, which differ in terms of the socio-demographic characteristics and variables related to the disease. ${ }^{12}$ The burden of HIV in Africa and the increasing expectations regarding the accessibility of HIV treatment and services have led to a need to assess the HRQoL in these populations. HRQoL has appeared as an essential element in assessing the impact of HAART. Although HAART may be considered a saviour by most people, the QoL of people on HAART is still of concern. HAART may lengthen life, but at a significant cost to the HRQoL of HIV-infected people. ${ }^{13}$

The more HAART improves the QoL of patients, the more difficult it becomes to maintain frequent contact with healthcare providers, leading to monthly appointments to obtain HAART being missed. ${ }^{14}$ On the other hand, the assessment of HRQoL in these patients has become important, as their well-being may be affected not only by treatment failure but also by other treatmentrelated toxicity. ${ }^{15}$ Studies have revealed that a higher level of education, good adherence, high income and CD4+ count $>200$ cells $/ \mathrm{mm}^{3}$ are associated with higher QoL in all domains. ${ }^{16,17}$ Various doubts, including AIDS-related disgrace and discrimination, and fears about the ability to get married and divulging their needs, are the major problems of HIV-positive patients on HAART. ${ }^{18}$ The degree of the influence of clinical parameters and socio-demographic factors on the HRQoL of HIV-positive people on HAART has its own impact on the illness and the complexity of the therapeutic regimen. ${ }^{19}$ It has been assumed that the day-today feelings of the person on HAART can be correlated to the viral load and CD4 cell readings. Furthermore, the QoL of people taking HAART has also been measured by the presence or absence of side effects of HAART. ${ }^{13}$

In Ethiopia, HIV/AIDS has been recognized not only as a health problem, but also as a development challenge. Despite the efforts to contain the spread of the infection and prolong the lives of infected people by increasing access to antiretroviral drugs and improving clinical care, there has been less focus on patients' QoL and associated factors in the country. ${ }^{2}$ So, the HRQoL of HIV-positive patients on HAART needs to be assessed. The high burden of HIV/ AIDS in Ethiopia, together with increasing accessibility of HIV treatment and services, have increased the need for the assessment of HRQoL in HIV-positive people on HAART.

Therefore, this study aimed to assess the HRQoL and its associated factors among HIV-positive people who were on HAART at Ambo General Hospital, Ethiopia.

\section{Methods}

\section{Study Area and Period}

The present study was conducted in the antiretroviral therapy (ART) clinic at Ambo General Hospital (AGH), 
which is situated in Ambo town, Oromia region, Ethiopia. Ambo town is an administrative town in the West Showa zone, located $114 \mathrm{~km}$ from Addis Ababa, the capital city of Ethiopia, to the west. The general hospital serves more than half-a-million people in the West Showa zone and people from the neighboring zones. Services provided in AGH include inpatient, outpatient, pediatrics, obstetrics and gynecology, and the ART clinic. AGH ART clinic has served around 5863 PLWHA, of whom around 3006 are currently on active treatment. This study was conducted from February 20 to May 20, 2019.

\section{Study Design}

The study design was a cross-sectional study, carried out in $\mathrm{AGH}$.

\section{Source Population}

The source population of this study was adult patients infected with HIV/AIDS attending AGH ART clinic who are on HAART.

\section{Study Population}

The study population comprised adult patients with HIV/ AIDS on HAART who visited the ART clinic of AGH and fulfilled the eligibility criteria.

\section{Inclusion Criteria}

- People infected with HIV/AIDS who were on followup at $\mathrm{AGH}$.

- Those who were $>18$ years old.

- Patients who were on HAART for longer than 6 months.

\section{Exclusion Criteria}

- Patients who were unwilling to take part in the study.

- Those with a mental disorder, hearing difficulty or any other serious health problems.

- Patients who were unable to provide the appropriate information and had incomplete medical records.

\section{Sample Size Determination}

The sample size was calculated using the following single population proportion formula:

was used for $Z_{\alpha / 2}^{2}, 50 \%$ for $P$ and $5 \%$ for $d$, and the sample size $(n)$ was accordingly found to be 384 . As the source population $(N)$ in the study area was 3006 , the sample size was corrected using the following correction formula:
Corrected sample size $n=n x N / n+N=340$

Therefore, the final sample size was found to be 340 .

\section{Sampling Technique and Procedure}

Patients were selected by a random sampling technique. Initially, the patient came to the ART pharmacy according to their appointment for a refill of medication. After that, the data collector determined which patient to collect the data from by randomly selecting the card number of the patient from the list of cards on each appointment date. While the prescription was being processed, the data collector gave the patient a brief explanation of the study objective and obtained their verbal consent on follow-up. Those who agreed to participate in the study were interviewed using the prepared questionnaire format. After a patient interview, clinical information was also collected from individual medical records.

\section{Study Variables \\ Dependent Variable \\ - Level of quality of life (global score of QoL).}

\section{Independent Variables}

- Socio-demographic variables: age, sex, marital status, educational status, family monthly income, residence, occupation.

- Clinical variables: CD4 count, WHO stage, duration on HAART, OIs, comorbidity, ADRs, cotrimoxazole and ionized preventive therapy (CPT and IPT) utilization, regimen change.

- Miscellaneous: currently ill, substance use, duration since testing positive for HIV, HIV status disclosure, family seropositive status, perceived baseline QoL, follow-up.

\section{Data Collection and Analysis}

Data were collected by selected and trained data collectors. The WHOQOL-HIV BREF was used to investigate the QoL of PLWHA receiving HAART. It consists of 31 items/facets: the 29 domain-specific items are used to measure individual QoL across the six domains. The six domain scores are: physical; psychological; level of independence; social relationships; environmental; and spirituality, religion and personal beliefs (SRPB). The other two items are used to measure patients' perception of their general QoL and health status. Individual items are rated on a five-point Likert scale, where 1 indicates low, negative perceptions and 5 indicates high, positive perceptions. 
Some items, such as pain and discomfort, dependence and medication, death and dying, and negative feelings, were not scaled in a positive direction, meaning that for these facets, higher scores do not denote higher QoL. To transform these scores in a positive direction, the formula $6-$ $X$ (where $X$ is the facet score) was used. ${ }^{20}$

The mean scores of items within each domain were used to calculate the domain score. Hence, the domain scores were calculated by multiplying the mean of all items within the domain by $4 .^{21}$ The participants were categorized into two groups, of high HRQoL and low HRQoL, using the mean of the HRQoL scores as the cutoff point. The tool was translated into the Afaan Oromo language and used for data collection.

\section{Data Entry and Analysis}

The collected data were entered and analyzed using SPSS version 20 for Windows. Descriptive statistics (frequency, mean and SD) were used for frequency distributions of responses. A binary logistic regression analysis was used to identify factors associated with low global scores of HRQoL. Accordingly, the crude odds ratio (COR) and adjusted odds ratio (AOR) were used to measure levels of the association during the univariate and multivariate analysis, respectively. During univariate analysis, those variables with a $P$-value $<0.05$ were allowed into the multivariate analysis. Statistically significant associations at the $95 \% \mathrm{CI}$ were set at a $P$-value of $<0.05$.

\section{Data Quality Control}

The questionnaire and data abstraction format were checked thoroughly for completeness before commencing the actual data collection. Pretesting was carried out on 5\% of the sample size. The data collector made frequent checks on the data collection process to ensure data quality. After collection, data were checked for completeness, clarity and consistency.

\section{Results}

\section{Socio-Demographic Characteristics}

In the current study, among the randomly selected patients, only 296 patients responded. Females accounted for 168 (56.8\%) of these. Out of these patients, 100 (33.8\%) had completed primary education and $186(62.8 \%)$ were married. Most of the studied patients $(124,41.9 \%)$ were older
Table I Socio-Demographic Characteristics of People Living with HIVIAIDS on Highly Active Antiretroviral Therapy at $\mathrm{AGH}$, in Ambo, West Shewa, Ethiopia, 2019

\begin{tabular}{|c|c|c|c|}
\hline Variable & Category & Frequency & Percentage \\
\hline \multirow[t]{2}{*}{ Sex } & Female & 168 & 56.8 \\
\hline & Male & 128 & 43.2 \\
\hline \multirow[t]{3}{*}{ Age (years) } & $18-30$ & 55 & 18.6 \\
\hline & $31-40$ & 117 & 39.5 \\
\hline & $>40$ & 124 & 41.9 \\
\hline \multirow{4}{*}{$\begin{array}{l}\text { Educational } \\
\text { level }\end{array}$} & Cannot read and write & 85 & 28.7 \\
\hline & Primary & 100 & 33.8 \\
\hline & Secondary & 60 & 20.3 \\
\hline & Tertiary & 51 & 17.2 \\
\hline \multirow{4}{*}{$\begin{array}{l}\text { Marital } \\
\text { status }\end{array}$} & Single & 32 & 10.8 \\
\hline & Married & 186 & 62.8 \\
\hline & Divorced & 42 & 14.2 \\
\hline & Widowed & 36 & 12.2 \\
\hline \multirow[t]{4}{*}{ Ethnicity } & Oromo & 227 & 76.7 \\
\hline & Amhara & 54 & 18.2 \\
\hline & Tigre & 2 & 7 \\
\hline & Other* & 13 & 4.4 \\
\hline \multirow[t]{4}{*}{ Religion } & Orthodox & 177 & 59.8 \\
\hline & Muslim & II & 3.7 \\
\hline & Protestant & 102 & 34.5 \\
\hline & Other** & 6 & 2.0 \\
\hline \multirow[t]{7}{*}{ Occupation } & Farmer & 63 & 21.3 \\
\hline & Government employee & 59 & 19.9 \\
\hline & Trade & 17 & 5.7 \\
\hline & Daily laborer & 66 & 22.3 \\
\hline & Housewife & 54 & 18.2 \\
\hline & Unemployed & 25 & 8.4 \\
\hline & Other*** & 12 & 4.1 \\
\hline \multirow[t]{2}{*}{ Residence } & Rural & 82 & 27.7 \\
\hline & Urban & 214 & 72.3 \\
\hline Monthly & $<1500$ & 154 & 52.0 \\
\hline $\begin{array}{l}\text { family } \\
\text { income }\end{array}$ & $\geq 1500$ & 142 & 48.0 \\
\hline Having & Yes & 232 & 78.4 \\
\hline children & No & 64 & 21.6 \\
\hline
\end{tabular}

Notes: *Gurage (9), Wolayita (4); **Waqefata (6); ***driver (4), mechanic (1), student (7).

than 40 years and 214 participants $(72.3 \%)$ were urban residents. The majority of the studied population (154, $52 \%$ ) earned a monthly family income below the poverty line (<1500 ETB monthly) (Table 1). 
Table 2 Perceived Health Status and Other Health-Related Information of People Living with HIV/AIDS on Highly Active Antiretroviral Therapy at AGH, in Ambo, West Shewa, Ethiopia, 2019

\begin{tabular}{|c|c|c|c|}
\hline Variable & Category & Frequency & Percentage \\
\hline \multirow[t]{5}{*}{ Perceived current health status } & Very poor & 2 & 7 \\
\hline & Poor & 18 & 6.1 \\
\hline & Neither poor nor good & 49 & 16.6 \\
\hline & Good & 125 & 42.2 \\
\hline & Very good & 102 & 34.5 \\
\hline \multirow[t]{2}{*}{ Currently ill } & Yes & 93 & 31.4 \\
\hline & No & 203 & 68.6 \\
\hline \multirow[t]{4}{*}{ Believed source of HIV infection } & Unprotected intercourse & 95 & 32.1 \\
\hline & Injected drug & 14 & 4.7 \\
\hline & Blood product & 7 & 2.4 \\
\hline & Unknown & 180 & 60.8 \\
\hline \multirow[t]{2}{*}{ Duration since testing HIV positive (years) } & $\leq 5$ & 104 & 35.1 \\
\hline & $>5$ & 192 & 64.9 \\
\hline \multirow[t]{2}{*}{ Disclosed HIV status to relative(s) } & Yes & 264 & 89.2 \\
\hline & No & 32 & 10.8 \\
\hline \multirow[t]{4}{*}{ Number of family members infected with HIV $(n=209)$} & I & 142 & 67.9 \\
\hline & 2 & 56 & 26.8 \\
\hline & 3 & 8 & 3.8 \\
\hline & 4 & 3 & 1.4 \\
\hline \multirow[t]{4}{*}{ Living environment } & Bad & 7 & 2.4 \\
\hline & Neither bad nor good & 78 & 26.4 \\
\hline & Good & 139 & 47.0 \\
\hline & Very good & 72 & 24.3 \\
\hline \multirow[t]{2}{*}{ Family support } & Yes & 195 & 65.9 \\
\hline & No & 101 & 34.1 \\
\hline \multirow[t]{4}{*}{ Social relationships } & Bad & 3 & 1.0 \\
\hline & Neither bad nor good & 18 & 6.1 \\
\hline & Good & $15 \mid$ & 51.0 \\
\hline & Very good & 124 & 41.9 \\
\hline \multirow[t]{2}{*}{ Recent experience of HIV stigma and discrimination } & Yes & 91 & 30.7 \\
\hline & No & 205 & 69.3 \\
\hline
\end{tabular}

Abbreviation: HIV, human immunodeficiency virus.

\section{Perceived Health Status and Other Health-Related Information}

Patients were asked to rate their current health status, and $125(42.2 \%) 102(34.5 \%)$ and $49(16.6 \%)$ rated their current health as good, very good and neither good nor bad, respectively. The majority of patients $(180,60.8 \%)$ could not ascertain the source of HIV infection, while 95 patients $(32.1 \%)$ admitted to a sexual relationship as the source of infection. The majority of the patients (192, $64.9 \%$ ) had a duration $>5$ years since testing positive for
HIV, and most $(264,89.2 \%)$ had disclosed their HIV status to their relatives. Regarding support, more than half (195, $65.9 \%$ ) of the studied population reported that they had family support (Table 2).

The majority of patients $(107,36.1 \%)$ rated their perceived baseline QoL as neither good nor bad. In total, 86 patients $(29.1 \%)$ were found to be current substance users, including users of khat and alcohol. The majority of patients $(184,62.2 \%)$ administered their ART drugs once per day (Table 3). 
Table 3 Health-Related Information and Drug-Taking Behavior of People Living with HIV/AIDS on Highly Active Antiretroviral Therapy at AGH, in Ambo, West Shewa, Ethiopia, 2019

\begin{tabular}{|c|c|c|c|}
\hline Variable & Category & Frequency & Percentage \\
\hline \multirow[t]{5}{*}{ Baseline perceived QoL (before HAART) } & Very bad & 36 & 12.2 \\
\hline & Bad & 57 & 19.3 \\
\hline & Neither bad nor good & 107 & 36.1 \\
\hline & Good & 88 & 29.7 \\
\hline & Very good & 8 & 2.7 \\
\hline \multirow[t]{2}{*}{ Ever used any substance } & Yes & 168 & 56.8 \\
\hline & No & 128 & 43.2 \\
\hline \multirow[t]{2}{*}{ Currently using any substance } & Yes & 86 & 29.1 \\
\hline & No & 210 & 70.9 \\
\hline \multirow[t]{3}{*}{ Type of current substance use $(n=93)$} & Alcohol & 66 & 71.0 \\
\hline & Khat & 19 & 20.4 \\
\hline & Cigarette & 8 & 8.6 \\
\hline \multirow[t]{2}{*}{ Frequency of ART administration per day } & 1 & 184 & 62.2 \\
\hline & 2 & 112 & 37.8 \\
\hline \multirow[t]{2}{*}{ Regular follow-up for HIV } & Yes & 260 & 87.8 \\
\hline & No & 36 & 12.2 \\
\hline \multirow[t]{4}{*}{ Relation with healthcare provider } & Bad & 3 & 1.0 \\
\hline & Neither bad nor good & 47 & 15.9 \\
\hline & Good & 133 & 44.9 \\
\hline & Very good & 113 & 38.2 \\
\hline
\end{tabular}

Abbreviations: ART, antiretroviral therapy; HIV, human immunodeficiency virus.

\section{Clinical Information}

The majority of the studied population (67.6\%) had a normal BMI. Only $32.4 \%$ of patients had a baseline CD4 count $\geq 350$ cells $/ \mathrm{mm}^{3}$ and $85.1 \%$ of them had the most recent CD4 count $\geq 350$ cells $/ \mathrm{mm}^{3}$. More than half of the patients had stage II and III disease at the start of enrollment to ART care, while the majority $(67.6 \%)$ had a current WHO clinical stage II disease. Among 287 patients for whom the most recent viral load was recorded, $78.7 \%$ had a viral load measurement of $\leq 1000$ copies $/ \mathrm{mL}$. The majority of the studied population had at least one OI and a small percentage (20.3\%) had at least one chronic comorbid disease (Table 4).

\section{Drug-Related Information}

More than half $(176,59.5 \%)$ of the patients initiated ART with the first line regimen (TDF+3TC+EFV), with 240 (81.1\%) remaining on the same ART regimen during their treatment. The vast majority of patients (258, 87.2\%) initiated cotrimoxazole as a preventive therapy and only 98 (33.4\%) reported adverse reactions related to ART. Among those patients who made a regimen change $(n=57)$, development of toxicity $(42.1 \%)$ was the major reason for changing (Table 5).

\section{Cronbach's Alpha and Level of Mean Scores}

The reliability of the WHOQOL-HIV BREF tool was high (Cronbach's $\alpha=0.951$ ). The mean scores of HRQoL were highest in the physical (15.07), psychological (14.78) and level of independence (14.63) domains, followed by the environmental and SRPB domains (Table 6).

\section{HRQoL Across the Six Domains and Overall HRQoL}

HRQoL was categorized into low and high for each domain using the mean of each domain as a cut-off point. Most of the respondents had a high score for low QoL in three domains: physical (57.1\%), environmental (55.1\%) and SRPB (53.4\%) (Figure 1). More than half $(53 \%)$ of the participants had low overall HRQoL, followed by $47 \%$ of patients with high global scores of HRQoL (Figure 2). 
Table 4 Clinical Information of People Living with HIVIAIDS on Highly Active Antiretroviral Therapy at AGH, in Ambo, West Shewa, Ethiopia, 2019

\begin{tabular}{|c|c|c|c|}
\hline Variable & Category & Frequency & Percentage \\
\hline \multirow[t]{3}{*}{ Baseline weight (kg) (before HAART) } & $<40$ & 18 & 6.1 \\
\hline & $40-60$ & 202 & 68.2 \\
\hline & $>60$ & 76 & 25.7 \\
\hline \multirow[t]{3}{*}{ Recent weight (kg) } & $<40$ & 10 & 3.4 \\
\hline & $40-60$ & 165 & 55.7 \\
\hline & $>60$ & $|2|$ & 40.9 \\
\hline \multirow[t]{4}{*}{ Recent BMI } & $<18.5$ & 61 & 20.6 \\
\hline & $18.5-24.99$ & 200 & 67.6 \\
\hline & $25-29.99$ & 29 & 9.8 \\
\hline & $>30$ & 6 & 2.0 \\
\hline \multirow[t]{4}{*}{ Baseline WHO clinical stage (before HAART) } & 1 & 72 & 24.3 \\
\hline & II & 87 & 29.4 \\
\hline & III & 128 & 43.2 \\
\hline & IV & 9 & 3.0 \\
\hline \multirow[t]{3}{*}{ Recent WHO clinical stage } & 1 & 85 & 28.7 \\
\hline & II & 200 & 67.6 \\
\hline & III & 11 & 3.7 \\
\hline \multirow[t]{2}{*}{ Baseline CD4 count (before HAART) } & $<350$ & 200 & 67.6 \\
\hline & $\geq 350$ & 96 & 32.4 \\
\hline \multirow[t]{2}{*}{ Recent CD4 count } & $<350$ & 44 & 14.9 \\
\hline & $\geq 350$ & 252 & 85.1 \\
\hline \multirow[t]{2}{*}{ Baseline VL $(n=193)$ (before HAART) } & $\leq 1000$ & 93 & 48.2 \\
\hline & $>1000$ & 100 & 51.8 \\
\hline \multirow[t]{2}{*}{ Recent VL ( $\mathrm{n}=287)$} & $\leq 1000$ & 226 & 78.7 \\
\hline & $>1000$ & 61 & 21.3 \\
\hline \multirow[t]{2}{*}{ Comorbidity } & Yes & 60 & 20.3 \\
\hline & No & 236 & 79.7 \\
\hline \multirow[t]{6}{*}{ Type of comorbidity $(n=60)$} & Asthma & 14 & 23.3 \\
\hline & Hypertension & 5 & 8.3 \\
\hline & Heart failure & 3 & 5.0 \\
\hline & Peptic ulcer disease & 15 & 25.0 \\
\hline & Epilepsy & 7 & 11.7 \\
\hline & Other* & 16 & 26.7 \\
\hline \multirow[t]{2}{*}{ Ols } & Yes & 99 & 33.4 \\
\hline & No & 197 & 66.6 \\
\hline \multirow[t]{6}{*}{ Type of OI $(n=|0|)$} & Tuberculosis & 22 & 21.8 \\
\hline & Toxoplasmosis & 2 & 2.0 \\
\hline & Pneumonia & 43 & 42.6 \\
\hline & Urinary tract infection & 17 & 16.8 \\
\hline & Oral candidiasis & 9 & 8.9 \\
\hline & Other** & 8 & 7.9 \\
\hline
\end{tabular}

Notes: *Rheumatoid arthritis (II), major depressive disorder (5); **bacterial infections (6), diarrhea (2).

Abbreviations: BMI, body mass index $\left(\mathrm{kg} / \mathrm{m}^{2}\right)$; CD4, CD4 count (cells/ $\left.\mathrm{mm}^{3}\right)$; Ol opportunistic infection; VL, viral load (copies/mL); WHO, World Health Organization. 
Table 5 Drug-Related Information of People Living with HIVIAIDS on Highly Active Antiretroviral Therapy at AGH, in Ambo, West Shewa, Ethiopia, 2019

\begin{tabular}{|c|c|c|c|}
\hline Variable & Category & Frequency & Percentage \\
\hline \multirow[t]{2}{*}{ CPT } & Yes & 258 & 87.2 \\
\hline & No & 38 & 12.8 \\
\hline \multirow[t]{2}{*}{ IPT } & Yes & 92 & 31.1 \\
\hline & No & 204 & 68.9 \\
\hline \multirow[t]{6}{*}{ Type of initial HAART regimen } & D4T/3TC/NVP & 22 & 7.4 \\
\hline & D4T/3TC/EFV & 12 & 4.1 \\
\hline & AZT/3TC/NVP & 60 & 20.3 \\
\hline & $\mathrm{AZT} / 3 \mathrm{TC} / \mathrm{EFV}$ & 20 & 6.8 \\
\hline & TDF/3TC/EFV & 176 & 59.5 \\
\hline & TDF/3TC/NVP & 6 & 2.0 \\
\hline \multirow[t]{4}{*}{ Total duration on HAART (years) } & $<1$ & 4 & 1.4 \\
\hline & $\mathrm{I}-5$ & 93 & 31.4 \\
\hline & $5-10$ & 127 & 42.9 \\
\hline & $>10$ & 72 & 24.3 \\
\hline \multirow[t]{2}{*}{ Initial regimen change } & Yes & 56 & 18.9 \\
\hline & No & 240 & 81.1 \\
\hline \multirow[t]{4}{*}{ Reasons for regimen change $(n=57)$} & Toxicity & 24 & 42.1 \\
\hline & Treatment failure & 16 & 28.1 \\
\hline & New TB & 8 & 14.0 \\
\hline & Not documented & 9 & 15.8 \\
\hline \multirow[t]{2}{*}{ ADRs $(n=293)$} & Yes & 98 & 33.4 \\
\hline & No & 195 & 66.6 \\
\hline
\end{tabular}

Abbreviations: ADR, adverse drug reaction; CPT, cotrimoxazole preventive therapy; HAART, highly active antiretroviral therapy; IPT, ionized preventive therapy.

\section{Factors Associated with Low HRQoL}

Binary logistic regression analysis was run to identify any association between different socio-demographic and clinical variables and global scores of HRQoL in the study population. Multivariate logistic analysis was run to

Table 6 Mean Scores and Cronbach's Alpha of HRQoL Domains for People Living with HIV/AIDS on Highly Active Antiretroviral Therapy at AGH, in Ambo, West Shewa, Ethiopia, 2019

\begin{tabular}{|l|l|l|}
\hline HRQoL Domain & $\begin{array}{l}\text { Cronbach's } \\
\alpha\end{array}$ & $\begin{array}{l}\text { Mean Score (SD) } \\
\text { (Out of 20) }\end{array}$ \\
\hline Physical & 0.933 & $15.07(3.470)$ \\
Psychological & 0.934 & $14.78(3.246)$ \\
Level of independence & 0.932 & $14.63(3.318)$ \\
Social relationships & 0.956 & $13.85(2.900)$ \\
Environmental & 0.939 & $14.31(2.605)$ \\
Spirituality, religion and & 0.950 & $14.15(3.239)$ \\
Personal beliefs (SRPB) & & $14.50(2.820)$ \\
Overall HRQoL & 0.951 & \\
\hline
\end{tabular}

Abbreviation: HRQoL, health-related quality of life. identify factors associated with low QoL. Those who were married were less likely to experience low overall HRQoL than single people (AOR: $4.41, P=0.024$ ). Those who earned $<1500$ ETB were more likely to experience low overall HRQoL than those who earned more (AOR: 4.27, $P=0.000$ ). Those with current illness were more likely to experience low overall QoL than those with no current illness (AOR: 32.29, $P=0.000$ ). Patients with no HIV-positive family members were more likely to experience lower overall QoL than those with one HIV-positive family member (AOR: 4.03, $P=0.003$ ) but less likely to experience low overall QoL than those with three or more HIV-positive family members (AOR: 0.03, $P=0.011$ ). Patients with recent stage I disease were less likely to experience low overall QoL than those with stage II (AOR: 0.07, $P=0.000$ ) (Table 7).

\section{Discussion}

In the current study, among randomly selected patients, only 296 patients responded, of whom females accounted 


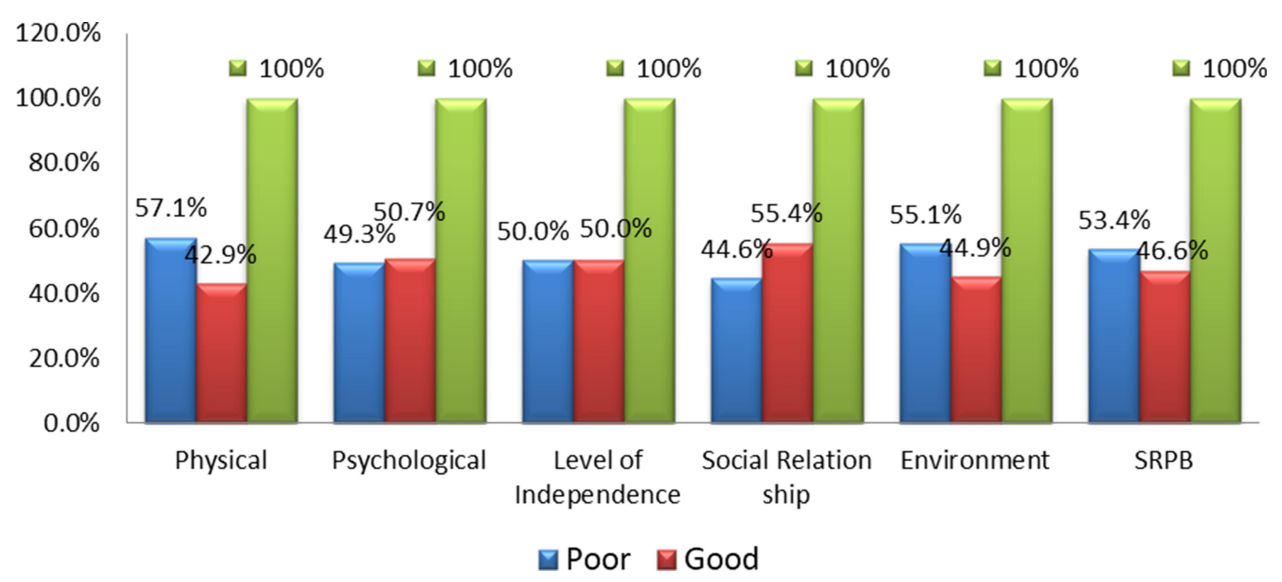

Figure I Level of HRQoL across the six domains for people living with HIV/AIDS on highly active antiretroviral therapy at AGH, in Ambo, West Shewa, Ethiopia, 20 I9.

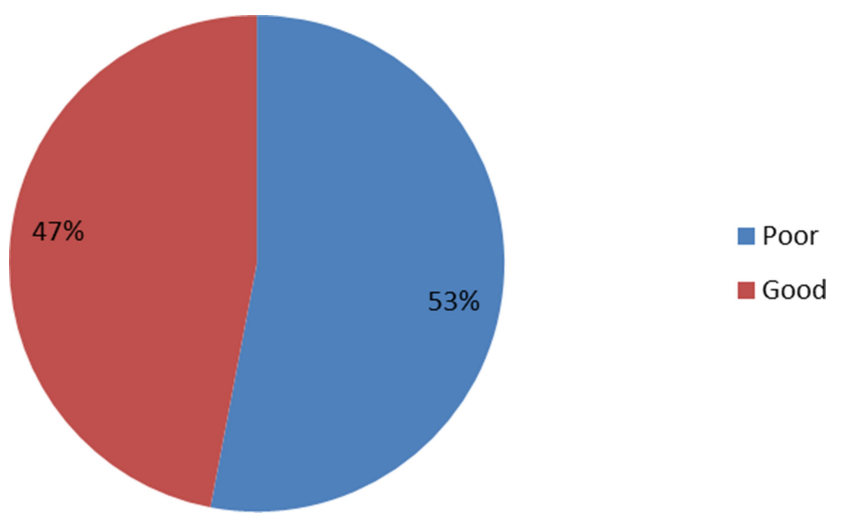

Figure 2 Level of overall HRQoL for people living with HIVIAIDS on highly active antiretroviral therapy at AGH, in Ambo, West Shewa, Ethiopia, 2019.

for $168(56.8 \%)$. In this study, the overall patient HRQoL score was categorized into two groups, high HRQoL and low HRQoL, using the mean of the HRQoL scores (14.5) on a scale of $0-20$ as the cut-off point. Based on this, the current study found that more than half $(53 \%)$ of the participants had low overall HRQoL. This result is consistent with other studies conducted in Ethiopia (56.4\%) and Bangladesh, in which more than half of the participants had low overall QoL. ${ }^{17,22,23}$

Besides determining the extent of HRQoL, this study found that factors such as current illness, recent stage II disease, not having family with HIV and having three or more HIV-positive family members, low monthly income and not being married were negatively associated with the HRQoL of PLWHA.

According to the present study, current illness was also found to be a significant determinant of HRQoL. Hence, patients who reported being currently ill had low overall HRQoL compared to those who did not currently feel ill
(AOR: $32.29, P=0.000$ ). This is in line with a study conducted in Nigeria, which revealed that participants who reported being currently ill had lower QoL $(P<0.001)$ in all domains. ${ }^{24}$ This could be attributed to the anxiety of the patients with this disease and their suffering from physical symptoms, which can have a negative impact on QoL.

Another finding was that a patient who had no HIV-positi ve family members was more likely to experience lower overall QoL than who had one HIV-positive family member (AOR: 4.03, $P=0.003$ ). This may be due to the stigma of the respondent in the family. Patients who earned $<1500$ ETB were more likely to experience low overall HRQoL than those who earned more (AOR: 4.27, $P=0.000$ ). This may be because of the anxiety of the patients to fulfill their basic needs. This finding is consistent with a study conducted in Ethiopia in which almost half $(202,47 \%)$ of respondents had low monthly income $(<500 \mathrm{ETB})^{22}$ and being wealthy was associated with better overall HRQoL. ${ }^{25}$ It is also consistent with research conducted in Estonia, which showed that employees with high income felt that they had a better QoL. ${ }^{26}$ Marital status also had a significant association with HRQoL, and this finding is consistent with a study conducted in Zimbabwe. ${ }^{27}$

Patients with WHO clinical stage I disease were less likely to experience low overall QoL than those with stage II (AOR: 0.07, $P=0.000$ ). This finding is consistent with studies conducted in Jimma, Ethiopia, ${ }^{28}$ and Bangladesh, in which the clinical stage was to be associated with overall HRQoL, ${ }^{16}$ and opposite to a study conducted in Zimbabwe. $^{27}$ The higher WHO clinical stages may be associated with limited day-to-day activities, which may eventually result in low HRQoL. In the current study, marital status was also associated with low overall HRQoL, in that those who were not married was more 
Table 7 Multivariate Logistic Regression Analysis of Factors Associated with Overall HRQoL of HIV Patients on HAART at AGH, in Ambo, West Shewa, Ethiopia, 2019

\begin{tabular}{|c|c|c|c|c|c|c|c|c|c|}
\hline \multicolumn{2}{|c|}{ Factors Associated with Overall HRQoL } & \multicolumn{2}{|c|}{ Low Overall HRQoL } & \multirow[t]{2}{*}{ COR } & \multirow[t]{2}{*}{$P$-value } & \multirow[t]{2}{*}{ AOR } & \multicolumn{2}{|l|}{$95 \% \mathrm{Cl}$} & \multirow[t]{2}{*}{$P$-value } \\
\hline & & Yes & No & & & & Lower & Upper & \\
\hline Marital status & $\begin{array}{l}\text { Single } \\
\text { Married } \\
\text { Divorced } \\
\text { Widowed }\end{array}$ & $\begin{array}{l}25 \\
78 \\
27 \\
27\end{array}$ & $\begin{array}{l}7 \\
108 \\
15 \\
9\end{array}$ & $\begin{array}{l}4.95 \\
1.98 \\
1.19\end{array}$ & $\begin{array}{l}0.000 \\
0.201 \\
0.762\end{array}$ & $\begin{array}{l}4.41 \\
0.64 \\
0.33\end{array}$ & $\begin{array}{l}1.22 \\
0.15 \\
0.07\end{array}$ & $\begin{array}{l}16.00 \\
2.80 \\
1.66\end{array}$ & $\begin{array}{l}0.024 \\
0.558 \\
0.180\end{array}$ \\
\hline Monthly family income & $\begin{array}{l}<1500 \\
\geq 1500\end{array}$ & $\begin{array}{l}98 \\
59\end{array}$ & $\begin{array}{l}56 \\
83\end{array}$ & 2.46 & 0.000 & 4.27 & 2.00 & 9.11 & 0.000 \\
\hline Current illness & $\begin{array}{l}\text { Yes } \\
\text { No }\end{array}$ & $\begin{array}{l}84 \\
73\end{array}$ & $\begin{array}{l}9 \\
130\end{array}$ & 16.6 & 0.000 & 32.29 & 11.59 & 89.97 & 0.000 \\
\hline Number of family members HIV positive & $\begin{array}{l}0 \\
1 \\
2 \\
\geq 3\end{array}$ & $\begin{array}{l}55 \\
59 \\
33 \\
10\end{array}$ & $\begin{array}{l}32 \\
83 \\
23 \\
1\end{array}$ & $\begin{array}{l}2.42 \\
1.20 \\
0.172\end{array}$ & $\begin{array}{l}0.002 \\
0.607 \\
0.100\end{array}$ & $\begin{array}{l}4.03 \\
0.79 \\
0.03\end{array}$ & $\begin{array}{l}1.63 \\
0.26 \\
0.002\end{array}$ & $\begin{array}{l}9.98 \\
2.39 \\
0.433\end{array}$ & $\begin{array}{l}0.003 \\
0.675 \\
0.011\end{array}$ \\
\hline Recent WHO clinical stage & $\begin{array}{l}\text { I } \\
\text { II } \\
\text { III }\end{array}$ & $\begin{array}{l}21 \\
129 \\
7\end{array}$ & $\begin{array}{l}64 \\
71 \\
4\end{array}$ & $\begin{array}{l}0.181 \\
0.188\end{array}$ & $\begin{array}{l}0.000 \\
0.013\end{array}$ & $\begin{array}{l}0.07 \\
0.20\end{array}$ & $\begin{array}{l}0.03 \\
0.04\end{array}$ & $\begin{array}{l}0.18 \\
1.10\end{array}$ & $\begin{array}{l}0.000 \\
0.064\end{array}$ \\
\hline
\end{tabular}

Abbreviations: COR, crude odds ratio; AOR, adjusted odds ratio.

likely to experience low overall HRQoL than married participants. This result is consistent with a study conducted in Jimma, Ethiopia. ${ }^{28}$

In this study, residence, educational level, having children, duration since testing positive for HIV, CPT, IPT and comorbidity were not significantly associated with HRQoL among HIV-infected people on HAART.

The current study has some limitations. The sample size was lower than the minimum required, and the design was a cross-sectional study, which has its own disadvantages. Patient-perceived illness is also one of the potential biases in determining QoL because of cultural differences. In addition to these limitations, patients may forget past events, especially data related to the time of HAART initiation.

\section{Conclusion}

This study found that more than half of HIV-positive people on HAART had low overall HRQoL. A majority of the respondents had low QoL on all of the domains of HRQoL. A monthly income of $<1500$ ETB, being not married, having current illness, having no HIV-positive family members, having three or more HIV-positive family members and recent WHO clinical stage were negatively associated with overall HRQoL.

\section{Abbreviations}

AGH, Ambo General Hospital; AIDS, acquired immune deficiency syndrome; ART, antiretroviral therapy; BMI, body mass index; HAART, highly active antiretroviral therapy; HIV, human immunodeficiency virus; OI, opportunistic infection; PLWHA, people living with HIV/AIDS; QoL, quality of life; SRPB, spirituality, religion and personal beliefs; WHO, World Health Organization; WHOQOL-HIV BREF, World Health Organization Quality of Life HIV Brief.

\section{Data Sharing Statement}

Data are available on request from the authors.

\section{Ethics Approval and Consent to Participate}

This study was conducted after a formal letter was requested and obtained from Ambo University, College of Medicine and Health Sciences, Department of Pharmacy. Then, the permission to collect data was obtained after official letters were written to the head of the ART clinic. Moreover, all other concerned bodies such as health professionals in each discipline were informed about the aim and purpose of the study. The issue of ensuring privacy and confidentiality of patient data was our top priority. Only the patient card number was used as 
the identifier for each participant. Based on the verbal consent form approved by Ambo University, the consent to participate was obtained from patients by informing them about the purpose of the study and the importance of their participation. Therefore, this study was conducted in accordance with the Declaration of Helsinki.

\section{Acknowledgment}

We extend our gratitude to Ambo General Hospital.

\section{Author Contributions}

All authors made a significant contribution to the work reported, whether that is in the conception, study design, execution, acquisition of data, analysis and interpretation, or in all these areas; took part in drafting, revising or critically reviewing the article; gave final approval of the version to be published; have agreed on the journal to which the article has been submitted; and agree to be accountable for all aspects of the work.

\section{Disclosure}

The authors declare that there are no conflicts of interest in this work.

\section{References}

1. World Health Organization: Regional office for Europe (2017). Fact sheets on sustainable development goals: health targets. World Health Organization: Regional office for Europe (2017). Fact sheets on sustainable development goals: health targets.

2. STAR Initiative, Unitaid and World Health Organization (2018). Knowing your status-then and now: Realizing the potential of HIV self-testing.

3. Gayle HD, Hill GL. Global impact of human immunodeficiency virus and AIDS. Clin Microbiol Rev. 2001;14:327-335. doi:10.1128/ CMR.14.2.327-335.2001

4. Kebede W. National Guidelines for Comprehensive HIV Prevention, Care and Treatment. Federal Ministry of Health; 2018.

5. WHO. ART failure and strategies for switching ART regimens in the WHO European Region. Report of the WHO expert consultation Copenhagen, German. 2007

6. Oguntibeju O. Quality of life of people living with HIV and AIDS and antiretroviral therapy. HIV/AIDS Res Palliat Care. 2012;4:117-124. doi:10.2147/HIV.S32321

7. WHO. WHOQOL-BREF Introduction, Administration, Scoring and Generic Version of the Assessment: Field Trial Version. Geneva: WHO; 1996.

8. Cummins RA. Beyond Rural Health to Well-Being: An Appraisal of the Comprehensive Quality of Life Scale - Fifth Edition Adelaide. Australia: School of Psychology, Deakin University; 1999.

9. Beard J, Feeley F, Rosen S. Economic and quality of life outcomes of antiretroviral therapy for HIV/AIDS in developing countries: a systematic literature review. AIDS Care. 2009;21(11):1343-1356. doi:10.1080/09540120902889926

10. Wilson IB, Cleary PD. Linking clinical variables with health-related quality of life: a conceptual model of patient outcomes. JAMA. 1995;273(1):59-65. doi:10.1001/jama.1995.03520250075037
11. Olusina A, Ohaeri JU. Subjective quality of life of recently discharged Nigerian psychiatric patients. Soc Psychiatry Psychiatr Epidemiol. 2003;38:707-714. doi:10.1007/s00127-0030691-7

12. Apodaca FM, Laguía A, Safreed-Harmon K, et al. Assessing quality of life in people with HIV in Spain: psychometric testing of the Spanish version of WHOQOL-HIV-BREF. Health Qual Life Outcomes. 2019;17:144. doi:10.1186/s12955-019-1208-8

13. Ntshakala TT, Mavundla TR, Dolamo BL. Quality of life domains relevant to people living with HIV and AIDS who are on antiretroviral therapy in Swaziland. Curationis. 2012;35(1):87. doi:10.4102/ curationis.v35i1.87

14. Collins D. Pretesting survey instruments: an overview of cognitive methods. Qual Life Res. 2003;12:229-238. doi:10.1023/ A: 1023254226592

15. Meuleners LB, Lee AH, Binns CW, et al. Quality of life for adolescents: assessing measurement properties using structural equation modeling. Qual Life Res. 2003;12(3):283-290. doi:10.1023/ A:1023221913292

16. Nonenoy S, Panza A, Plipat T, et al. Health related quality of life among persons living with HIV/AIDS in three hospitals in Thailand. $J$ Health Res. 2009;24.

17. Imam MH, Karim MR, Ferdous C, et al. Health related quality of life among the people living with HIV. Bangladesh Med Res Counc Bull. 2011;37:1-6. doi:10.3329/bmrcb.v37i1.7791

18. World Health Organization. Treating 3million by 2005 Making It Happen; the WHO Strategy: The WHO and UNAIDS Global Initiative to Provide Antiretroviral Therapy to 3 Million People with HIV/AIDS in Developing Countries by the End of 2005. World Health Organization; 2003.

19. Klug Passos SM, Mattos Souza LD. An evaluation of quality of life and its determinants among people living with HIV/AIDS from Southern Brazil. Cad Saúde Pública. 2015;31(4):800-814. doi:10.1590/0102-311X00000514

20. World Health Organization. WHOQOL-HIV BREF-Mental Health: Evidence and Research. Geneva, Switzerland: WHO; 2002.

21. World Health Organization. WHOQOL-HIV Instrument-User's Manual Scoring and Coding for the WHOQOL-HIV Instruments. Geneva, Switzerland: WHO; 2002.

22. Alemu A, Yenealem A, Feleke A, et al. Health related quality of life assessment and associated factors among people on highly active antiretroviral therapy at Felege Hiwot Referral Hospital, Bahir Dar, North West Ethiopia. J AIDS Clin Res. 2013;5:1.

23. Negera GZ, Mega TA. Health-related quality of life among admitted HIV/AIDS patients in selected Ethiopian Tertiary care settings: a cross-sectional study. Open Public Health J. 2019;12:532-540. doi:10.2174/1874944501912010532

24. Akinboro A, Akinyemi S, Olaitan P, et al. Quality of life of Nigerians living with human immunodeficiency virus. Pan Afr Med J. 2014;18:234.

25. Weldsilase YA, Likka MH, Wakayo T, et al. Health-related quality of life and associated factors among women on antiretroviral therapy in health facilities of Jimma Town, Southwest Ethiopia. Adv Public Health. 2018;2018:pp1-12. doi:10.1155/2018/ 5965343

26. Rüütel K, Pisarev H, Loit H, et al. Factors influencing quality of life of people living with HIV in Estonia. J Int AIDS Soc. 2009;12:13. doi:10.1186/1758-2652-12-13

27. Abdrrahman SS, Fitsum ST, Wondwessen W, et al. Health related quality of life of HIV/AIDS patients on highly active anti-retroviral therapy at a university referral hospital in Ethiopia. BMC Health Serv Res. 2017;17:737. doi:10.1186/s12913-017-2714-1

28. Mafirakureva N, Dzingirai B, Postma MJ, et al. Health- related quality of life in HIV/AIDS patients on antiretroviral therapy at a tertiary care facility in Zimbabwe. AIDS Care. 2016;28 (7):904-912. doi:10.1080/09540121.2016.1173639 


\section{Publish your work in this journal}

HIV/AIDS - Research and Palliative Care is an international, peerreviewed open-access journal focusing on advances in research in HIV, its clinical progression and management options including antiviral treatment, palliative care and public healthcare policies to control viral spread. The manuscript management system is completely online and includes a very quick and fair peer-review system, which is all easy to use. Visit http://www.dovepress.com/testimonials.php to read real quotes from published authors. 